\title{
Logistical transportation routes optimization for Brazilian soybean: an application of the origin-destination matrix
}

\author{
Andréa Leda Ramos de Oliveira ${ }^{1^{*}}$ (D) Monique Filassi ${ }^{1}$ (i) Bruna Fernanda Ribeiro Lopes ${ }^{1}$ (D) \\ Karina Braga Marsola ${ }^{1}$ (D)
}

${ }^{1}$ Laboratório de Logística e Comercialização Agroindustrial (LOGICOM), Faculdade de Engenharia Agrícola (FEAGRI), Universidade Estadual de Campinas (UNICAMP), 13083-875, Campinas, SP, Brasil. E-mail: aleda@unicamp.br. "Corresponding author.

ABSTRACT: The last Brazilian agricultural frontier known as MATOPIBA, an acronym for the states of Maranhão, Tocantins, Piaui and Bahia, is a region that has stood out in the scenario of modern large-scale agriculture intensive in capital and technology. However, barriers related to the transportation system, especially regarding the high logistics costs, have been negatively impacting this sector. To optimize the performance of this chain, a model for minimizing transportation costs was developed, using linear programming with an origin-destination matrix. The purpose of this paper was to evaluate whether the use of the North-South Railroad has potential as a new alternative intermodal route for soybean export from the MATOPIBA region, in order to minimize the transportation costs and promote the viability of new ports located in the northeast region of the country. This configuration can also contribute to reduce the overload of Santos Port (SP). Two scenarios were proposed based on the 2016/17 harvest of soybeanwhere the first scenario (A) consisted only of road routes, while the second (B), in addition to these routes, incorporated road-rail and road-water way intermodal routes. As a result, total transportation cost was reduced by $30 \%$ in scenario B and about half of all cargo was shipped by the new intermodal road-rail route to the Itaqui Port in the Northeast region. This configuration promotes a more sustainable logistics chain for soy, with more rational use of transport modes and decentralization of investments to other regions.

Key words: agribusiness, commodities, operational research, origin-destination matrix, optimization.

Otimização das rotas logísticas de transporte da soja brasileira: uma aplicação da matriz origem-destino

RESUMO: A última fronteira agrícola brasileira conhecida como MATOPIBA, acrônimo de Maranhão, Tocantins, Piaui e Bahia, é uma região que vem se destacando no cenário da agricultura moderna de grande escala e intensiva em capital e tecnologia. No entanto, entraves relacionados ao sistema de transporte, principalmente com relação aos altos custos logísticos, vêm impactando negativamente esse setor. Para otimizar o desempenho dessa cadeia foi desenvolvido um modelo de minimização dos custos de transporte, operacionalizado por programação linear sob a forma de uma matriz origem-destino. A proposta deste trabalho é avaliar se a utilização da Ferrovia Norte-Sul apresenta potencial como nova rota intermodal alternativa para a exportação da soja da região do MATOPIBA, afim de minimizar o custo com transporte e promover a viabilidade de novos portos localizados na região Nordeste do país. Esta configuração também pode contribuir para reduzir a sobrecarga do Porto de Santos (SP). Dois cenários foram propostos com base na safra 2016/17, onde o primeiro cenário (A) foi composto apenas por rotas rodoviárias, enquanto o segundo (B), além dessas rotas foram incorporadas as rotas intermodais rodoferroviária e rodohidroviária. Como resultado, o custo total de transporte teve uma redução de 30\% no cenário B, e cerca da metade de toda a carga foi escoada pela nova rota intermodal rodoferroviária com destino ao Porto de Itaqui na região Nordeste. Esta configuração promove uma logística de distribuição mais sustentável para a soja, com uso mais racional dos modais de transporte e a descentralização dos investimentos para outras regiões.

Palavras-chave: agronegócio, commodities, matriz origem-destino, otimização, pesquisa operacional.

\section{INTRODUCTION}

The expansion of the agricultural frontier to new areas of the Center-Northeast of Brazil provides production gains of important agricultural commodities and; consequently, greater insertion in the world food trade. The term MATOPIBA refers to the region comprising areas of Maranhão, Tocantins,
Piauí and Bahia states. According to the Ministry of Agriculture, Livestock and Supply (BRASIL, 2017), the crop area for grains in this region should expand by $15.0 \%$ over the next 10 years and grain production in these states exceeded 20.5 million tons in 2016/17 and should exceed 26.5 million in 2026/27.

Soybean is one of the main agricultural crops produced in Brazil, which has the leadership 
in world exports and the second position in the world production ranking. Its expressive growth in the last three decades has made soybeans responsible for about $50 \%$ of the country's grain crop area, with a production that exceeded 115.0 million tons in the $2018 / 2019$ crop, about $64 \%$ of which are for exportation (CONAB, 2020). This increase in production is mainly associated with productivity gains that are the result of technological advances, best management practices and producer efficiency (CONAB, 2016). These data reflected the economic importance of this commodity in generating foreign currency and maintaining the positive balance of the Brazilian trade balance.

The expected variation in soybean exports in $2026 / 27$ compared to $2016 / 17$ is an increase of around $33.5 \%$ (BRASIL, 2017). In recent years, according to the Ministry of Economy (BRASIL, 2020), the participation of ports in the North and Northeast regions of Brazilian soybean exports increased from $17 \%$ in 2013 to $31 \%$ in 2019 .

Despite the prominent position on the world stage as a major exporter of commodities, it is observable that the Brazilian logistics system still has deficiencies. In many cases, highways are the only alternative, due to the lack of waterways and railways that connect long distances and that are close to the productive regions (ROULET et al., 2016). In the case of Brazil, the road system is the main mode used for the transportation of agricultural cargo, most Brazilian soybean is transported by road (CORREA; RAMOS, 2010; TOLOI, et al., 2019). The result of these limitations can be illustrated by the extensive truck queues at major export ports, the long waiting times for ships to dock and the failure to meet delivery times for international buyers. This scenario has led to increased logistics costs and reduced soybean competitiveness in the world market (OLIVEIRA; ALVIM, 2017). It is also advantageous that intermodality can save environmental resources and reduce greenhouse gas emissions (AISHA et al., 2020; WIEGMANS; JANIC, 2019), specially regarding railway integration (ADITJANDRA et al., 2016).

It is noteworthy that the modes of transport have an operational efficiency as to the type of cargo they move. In the case of most agricultural products, rail and waterway systems are the most suitable as they have operational characteristics for the transport of high volume and low value-added products (SOUZA et al., 2016). In 2016, 25.4 million tons of soybeans were handled through Brazilian highways to export ports, while 22.5 million tons of the same cereal were transported through railways and only 5.5 million tons through waterways (CONAB, 2016).
The North-South Railway (FNS) was designed to be the structuring axis of the Brazilian rail system, connecting the five Brazilian regions through two main railroads and providing access to various ports and export corridors. When fully completed, it will have a length of $4,155.6 \mathrm{~km}$ and will cross the states of Pará, Maranhão, Tocantins, Goiás, Minas Gerais, São Paulo, Mato Grosso do Sul, Paraná, Santa Catarina and Rio Grande do Sul. In the north and northeast of the country, the railway is 720 $\mathrm{km}$ long on the Açailândia/MA - Palmas/TO stretch and $855 \mathrm{~km}$ long on the Palmas/TO - Anápolis/GO stretch, which are already in operation. In Açailândia/ MA, the railroad connects to the Carajás Railway EFC that accesses the São Luís/MA port complex. In Figueirópolis/TO, FNS will connect to the East-West Integration Rail - FIOL which will allow access to the South Port, which will be built near Ilhéus/BA (VALEC, 2018).

The use of origin-destination matrices to estimate soybean export flows is a technique with wide applicability in economic studies, as it allows the minimization of costs and the comparison between different scenarios. Lack of information about origins and destinations in transportation planning can lead to inefficient system operations, high costs and insufficient transportation supply (KAWAMOTO, 2003). To model cargo transport demand, it is necessary to consider the existence of several dimensions (different types of cargo, volumes, weights and number of trips) under the control of different decision makers (shippers, carriers, drivers and dispatchers) who interact in a dynamic environment (SOUZA, et al. 2010). This is a suitable instrument for transport-related studies, including scheduling and planning, evaluation of flow alternatives and traffic flow simulation (HAMERSLAG; IMMERS, 1988).

MARTINS \& CAIXETA FILHO (1998) used this method to rationalize the use of transportation infrastructure in corn, soybean, soybean meal and wheat commercialization in the state of Paraná, using freight as a basis. In the study by OLIVEIRA et al. (2013), the origin-destination matrix was used to verify the advantages of using intermodality in the routes used to move sugar produced in the state of São Paulo to export ports. In OLIVEIRA et al. (2015), this method was used to estimate the optimal export flows of Brazilian maize produced in the state of Mato Grosso to the main export ports of this cereal. The flow of Brazilian soybean occurs through unimodal and intermodal transport systems already discussed in the studies by SOUZA et al. (2016); CORREA 
\& RAMOS (2010), where both studies show the economic gains from intermodality. Regarding the evaluation of the best options for the transportation of soybeans through transport optimization models, LOPES et al. (2016) considered in their transport cost minimization model all the producing regions of Brazil destined for Asia, the conclusion was that exports through the ports of northern Brazil increased the grain's competitiveness. Already DE LA CRUZ et al. (2010) evaluated the flow of soy produced in the states of Tocantins, Piauí and Maranhão through the application of a spatial balance model and concluded that the use of intermodality was the best option for the flow of soybean. However, KUSSANO \& BATALHA (2012) pointed out that the flow through intermodal means does not always have the lowest cost, mainly due to the low logistical infrastructure.

In view of this impasse of the evaluated literature on the use of intermodality in the flow of grains to improve competitiveness, this study proposed to complement other studies that use transport optimization models to evaluate the best routes for product flow. The objective was to point out directions for the optimization of the soybean logistics produced in the MATOPIBA region considering the 2016/17 harvest, through a linear transportation optimization model, above all evaluating the use of the North-South Railway as a potential alternative route for transporting the production to ports in the Northeast region.

An important contribution of this research was to place the most recent Brazilian agricultural frontier at the center of the analysis. The unique character of the MATOPIBA region, identified by some authors as the "last agricultural frontier in the world" (MIRANDA et al., 2014; FAVARETO et al., 2019), promoted an understanding of the national integration process in this region.

The increasing expansion of MATOPIBA, with state funding through subsidized credit and investment in technology, added to the favorable conditions, such as land prices, low slope of the soil, proximity to Porto de Itaqui, among other positive points, led the region to grow its production at rates above national production, currently accounting for about $10 \%$ of grain production in Brazil (PEREIRA et al., 2018; FAVARETO et al., 2019). However, the established infrastructure is still poor and the region still has bottlenecks to be overcome (PEREIRA et al., 2018), a factor that limits the immediate use of the region's economic potential (BUAINAIN et al., 2018) and the upward trajectory of agricultural production.
Another differentiating element in the implementation of the origin-destination matrix based on linear programming in this study, was the fact that the total logistical cost also considered: the freight price for the modes plus the port tariff of each port and the transshipment cost for intermodal options. The other studies in the literature, such as MARTINS \& CAIXETA FILHO $(1998,1999)$ and LEITE \& FIGUEIREDO (2006), considered only the distance traveled or only the cost of transportation, this singular characteristic is an advance of the model incorporating the real aspects of Brazilian soybean logistics, in addition to being an additional element of accuracy.

\section{MATERIALS AND METHODS}

Modeling techniques used to estimate the transport flows of agricultural products are based on optimization (linear, non-linear and integer) and simulation models (YANG et al., 2013). Both methods have been used to simulate transport flows; however, optimization techniques (linear or not) are more assertive in the decision-making process to find an optimal or the most efficient solution, in order to achieve a goal, while satisfying a set of restrictions. Usually, the goal is to maximize or minimize an analytical mathematical expression with a large number of variables. Simulation techniques, on the other hand, evaluate a large number of alternatives in different scenarios identified by decision makers. It is essential to understand that the simulation supports the decision through the evaluation of predefined options, but does not generate the best possible strategies (YANG et al., 2013).

To reach the objective of the study it was necessary to develop a mathematical model that identified the lower cost logistics routes and with the origin-destination matrix method two scenarios were constructed.

Generally speaking, in an origindestination matrix the rows represent the origins $i$, in this case the states of Maranhão (MA), Tocantins (TO), Piauí (PI) and Bahia (BA) and the columns represent the destinations $j$, being the ports of Itaqui (MA), Aratu (BA) and Santos (SP) (Table 1). Point O $i$ reflects the total flows that have as their principle region $i$ and point $\mathrm{D} j$ equals the total flows destined for region $j$. The Tij elements represent the flow of produce moved between region $i$ and region $j$ (Table 1).

For the application of the matrix, we have the following mathematical model:

Minimize $Z=\sum_{i=1}^{y} \sum_{j=1}^{y} C_{i j} T_{i j}$ 
Table 1 - General model of a origin-destination matrix.

\begin{tabular}{|c|c|c|c|c|c|c|}
\hline \multirow[t]{2}{*}{ Origin } & \multicolumn{5}{|c|}{ Destination } & \multirow[t]{2}{*}{$\sum_{j} T_{i j}=T$} \\
\hline & 1 & 2 & 3 & $J$ & $Y$ & \\
\hline 1 & $T_{11}$ & $T_{12}$ & $T_{13}$ & $T_{1 j}$ & $T_{1 y}$ & $O_{1}$ \\
\hline 2 & $T_{21}$ & $T_{22}$ & $T_{23}$ & $T_{2 j}$ & $T_{2 y}$ & $\mathrm{O}_{2}$ \\
\hline 3 & $T_{31}$ & $T_{32}$ & $T_{33}$ & $T_{3 j}$ & $T_{3 y}$ & $\mathrm{O}_{3}$ \\
\hline$I$ & $T_{i 1}$ & $T_{i 2}$ & $T_{i 2}$ & $T_{i j}$ & $T_{i y}$ & $O_{i}$ \\
\hline . & . & . & . & . & . & . \\
\hline$Y$ & $T_{y 1}$ & $T_{y 2}$ & $T_{y 3}$ & $T_{y j}$ & $T_{y y}$ & $O_{y}$ \\
\hline$\sum_{i} T_{i j}$ & $D_{1}$ & $D_{2}$ & $D_{3}$ & $D_{j}$ & $D_{y}$ & $\sum_{i} T_{i j}=T$ \\
\hline
\end{tabular}

Source: Adapted from MARTINS \& CAIXETA FILHO (1998)

subject to

$$
\begin{aligned}
& \sum_{j=1}^{y} T_{i j} \leq O_{i}, \text { for all } i \\
& \sum_{i=1}^{y} T_{i j} \leq D_{j}, \text { for all } j
\end{aligned}
$$

where:

$C_{i j}=F_{i j}+P_{i j}$

being,

$Z=$ value of the objective function.

$C i j=$ total cost of transport between the supply region of origin $i$ and the port of destination $j$.

$F i j=$ cost of freight between the supply region $i$ and the port of destination $j$.

$P i j=$ port cost of the port of destination $j$.

$T i j=$ quantity exported from soybean from supply region of origin $i$ to the port of destination $j$.

$O i=$ Soybean supply by region $i$.

$D j=$ Soybean demand by port $j$.

The total Cij transport cost was calculated according to eq. (4), based on the 2017 Fij road freight, plus the transshipment fee for intermodal options and the port tariff of each $\mathrm{P} j$ port.

The transport costs of road and rail modes in the model were estimated using linear equations based on the distances between the loading and receiving points (origin/destination). The behavior of the modal cost (response variable) was analyzed using a multiple linear regression model. A database of monthly road freight rates practiced throughout the Brazilian territory in 2017 was used, based on data from the Freight Information System (SIFRECA, 2018). Thus, for the road modal, it was assumed that there is a different behavior for freight with distances up to 500 kilometers and greater than
500 kilometers (explanatory variables). For the road modal. we have:

$Y=\beta X+\varepsilon$

$y=\beta_{0}+\beta_{1} \delta X+\beta_{2}(1-\delta) X+\varepsilon$

where:

$\delta=\left\{\begin{array}{l}1 \text { if distance } \geq 500 \\ 0 \text { if distance }<500\end{array}\right.$

being,

$Y=$ freight in $\mathrm{U} \$ /$ tons

$X=$ distance in $\mathrm{km}$

$\beta=$ regression coefficient

$\delta=$ binary variable

$\varepsilon=$ random error

For rail transport, the equations were developed in the same way as the road modal, with the reference distance found being of 700 kilometers. The railway freight, the waterway freight, the transshipment rate for intermodal options and the port tariff of each $\mathrm{P} j$ port were estimated based on the study by OLIVEIRA \& ALVIM (2017).

The variable $\mathrm{O} i$ quantity of soybean supply by region $i$ was represented by the production volume of the states of the MATOPIBA region in the 2016/17 harvest (Table 2). The production data were based on CONAB (2020). The variable $\mathrm{D} j$ is the quantity of soybean by portand considered the volume exported by the ports of Itaqui (MA), Aratu (BA) and Santos (SP) in 2017 (Table 2). Exports by port were based on BRASIL (2020).

The road network, transport routes, producing regions and export ports considered in the model are shown in figure 1. For example, in the road-rail option with the North-South Railway (R2), soybean leaves the producing regions by truck until the municipality of Porto Nacional (TO), which has 
Table 2 - Soybean supply and demand from MATOPIBA region and export ports, 2017 (thousand tonnes).

\begin{tabular}{lc}
\hline Supply regions $(\mathrm{O} i)$ & Supply volume $(\mathrm{O} i)$ \\
\hline Maranhão & $2,473.3$ \\
Tocantins & $2,826.4$ \\
\hline Piauí & $2,048.1$ \\
Bahia & $5,123.3$ \\
Total MATOPIBA & $12,471.1$ \\
\hline Demand regions (Dj) & Demand volume (Dj) \\
\hline Santos - SP & $16,589.0$ \\
\hline Itaqui - MA & $6,128.0$ \\
\hline Aratu - BA & $3,168.0$ \\
\hline Total Demand & $25,885.0$ \\
\hline
\end{tabular}

Source: CONAB (2020); BRASIL (2020).

a rail transfer terminal, and leaves there by rail to the Port of Itaqui (Figure 1). There is an alternative road and road route (R4) in which the cargo goes by truck to São Simão (GO), a municipality where a waterway transfer terminal is located, and from there it goes by waterway to the Port of Santos (SP) (Figure 1).

In scenario $\mathrm{A}$, it was considered that the four states of Maranhão, Tocantins, Piauí and Bahia would flow their soybean production to the ports of Itaqui (MA), Aratu (BA) and Santos (SP), only by road, using the routes (R1), (R3) and (R5) (Figure 1, Figure 2, Table 2). In scenario $\mathrm{B}$, in addition to the previous road routes, intermodal (R2) and (R4) routes to the same ports were added, except for the Port of Aratu, which only has access by road. Where route (R2) uses the North-South Railway, and route (R4) uses the Tietê-Paraná Waterway (Figure 1, Figure 2 and Table 2).

The distances of the above routes were calculated from the weighted average of the three main soybean producing municipalities of each state belonging to the MATOPIBA region, namely: Tasso Fragoso (MA), Sambaíba (MA), Brejo (MA), Lagoa da Confusão (TO), Mateiros (TO), Porto Nacional (TO), Baixa Grande do Ribeiro (PI), Uruçuí (PI), Ribeiro Gonçalves (PI), Formosa do Rio Preto (BA) and São Desidério (BA).

The total logistical costs here are comprised of transportation cost (A), transshipment (B) and port tariff (C). Table 3 shows these costs and the distances traveled in each road segment. The costs involved are real data corresponding to what was practiced in 2017, based on OLIVEIRA \& ALVIM (2017) and SIFRECA (2018).
For the best scenario obtained, a sensitivity analysis was performed to assess the behavior of the matrix generated when the cost of transport varied. Thus, the price of road freight was varied by $15 \%$ and $25 \%$, increase and decrease, keeping the other cost variables fixed. Likewise, a variation of $15 \%$ and $25 \%$ in price for rail and waterway freight was made.

\section{RESULTS AND DISCUSSION}

Comparison of minimized transportation costs between the two scenarios under analysis was performed using the objective function results. The optimal result reported in scenario B was $\$ 1.4$ billion, its total cost was $30 \%$ lower than scenario A, after the addition of intermodal routes. This result can be explained because soybean transportation to the ports is carried out by road, railway, and waterway. When comparing the difficulties encountered in each of these modes, specialists from large companies (Abiove, Archer Daniels Midland Company - ADM, Bunge, Caramuru Alimentos S/A, Embrapa and others) in the soybean export sector point out that for the road modal, in addition to the low quality of the roads, costs are a serious problem, while for the rail and waterway modes, the biggest problem is the lack of availability in several Brazilian regions (FILASSI, 2019). For this reason, the use of intermodal routes, where not only highways are used to transport soybean, has a direct effect on costs.

The study by OLIVEIRA et al. (2015) for soybean distribution, also pointed out that the intermodal option, especially the road-rail route, was 


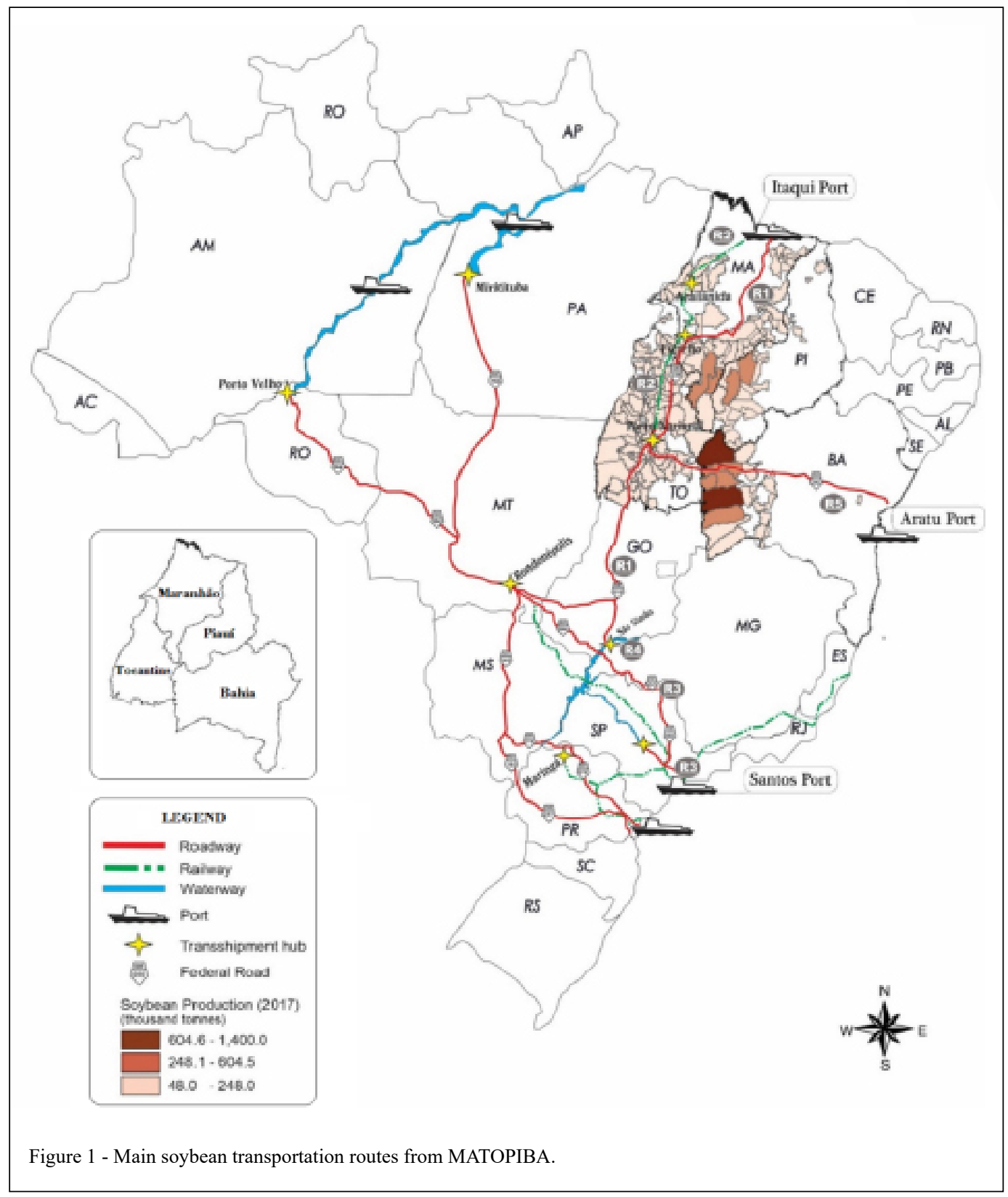

the most efficient and viable way to flow soybean production from the Midwest of the country.

In scenario A (Table 4), approximately $49.1 \%$ of the total volume transported from the four states that make up the MATOPIBA region was exported through the Itaqui Port via the roadroute (R1). The ports of Santos and Aratu were responsible for $25.5 \%$ and $25.4 \%$ of exports by road (R3) and (R5), respectively. The study by TUNDE \& ADENIYI (2012) examined the impact of road transport on agricultural development in Nigeria and concluded that an improvement in the road transport system will lead to increased production by farmers.

For this scenario, the optimal destination was the Itaqui Port, since the distance of the routes, together with the capacity of the origin and destination points influenced this model (Figure 3). The state of Bahia behaved differently from the others, as it was the only state not to flow any of its production through the Port of Itaqui.

Ciência Rural, v.51, n.2, 2021. 


\begin{tabular}{|l|l|l|}
\hline Code & Routes \\
\hline R1 & Roadway to Itaqui Port (MA) \\
R2 & $\begin{array}{l}\text { Road and Railway to Itaqui Port (MA) } \\
\text { transshipment at Porto Nacional (TO) } \\
\text { R3 }\end{array}$ & $\begin{array}{l}\text { Roadway to Santos Port (SP) } \\
\text { at São Simão Port (GO) }\end{array}$ \\
\hline R4 & $\begin{array}{l}\text { Roadway to Aratu Port (BA) } \\
\text { R5 }\end{array}$
\end{tabular}

Figure 2 - Routes and modes of transportation in scenarios A and B.

The proximity of ports to major shipping routes, as GORDON et al. (2005) and WU \& LIN (2008) found, are key factors for port efficiency. According to CASACA et al. (2017), with infrastructure improvements for the flow of agricultural production from the North and Northeast region, a significant percentage of the cargo currently transferred to the South and Southeast ports will be destined to the Northern ports, increasing Brazilian competitiveness in the global market.

In scenario B (Table 5), approximately $74.6 \%$ of the total volume handled was exported by the Port of Itaqui, but now the road route (R1) represented $34.1 \%$ of this total and the road-railway route (R2) represented $65.9 \%$. MARTINS \& CAIXETA FILHO (1999) used a source-destination model to investigate the use of transport infrastructure in the commercialization of soy and bran in the state of Paraná based on freight, also signaled a very significant increase in efficiency in logistics with the use of railways. Also, the ports of the northeast region of Brazil have a strategic location, which can lead to more competitive freights and shorter travel times. It also confirmed the feasibility of the railwayto handle large quantities of agricultural cargo.

The remaining $25.4 \%$ of the total volume was carried by road (R5) to Aratu Port, as well as in scenario A. LEITE \& FIGUEIREDO (2006) identified the best alternatives for the flow of cotton from the state of Bahia - Brazil considering a scenario of increased port investments in the Port of Aratu (BA).

It can be highlighted that the routes (R3) and (R4) bound for Santos Port were not activated, despite (R4) being intermodal. This result reflected the cost of freight, which is higher on these two routes than on the others, also as a result of the distance between the origin (cities) and the destination of cargo (ports) (Figure 4).

A sensitivity analysis in scenario $\mathrm{B}$, which presented the best results, was conducted in order to assess the possible implications in the configuration of flows when there aresudden variations in freight pricesfor the transport modes. Variations of $15-25 \%$ on road freight in scenario B did not change the result of the optimization. Likewise, variations of $15-25 \%$ in rail and waterway freight were also made, and the configuration of the origin-destination matrix remained the same. This showed that scenario B already presents the best possible configuration and the inclusion of a non-active route, for example to the Port of Santos, would need to suffer a very drastic cost reduction to be part of the optimal solution.

\section{CONCLUSION}

The advances of agribusiness are being followed in synchrony by some segments of the 
Table 3 - Transportation routes, distances by modes and total logistical cost, 2017.

\begin{tabular}{|c|c|c|c|c|c|c|c|c|c|}
\hline Supply & Port & Route & ------------ & istance $(\mathrm{k} 1$ & |)------------- & $\begin{array}{c}\text { Transportation } \\
\text { costs }\end{array}$ & Transshipment & $\begin{array}{l}\text { Port } \\
\text { Tariff }\end{array}$ & $\begin{array}{c}\text { Total } \\
\text { logistical }\end{array}$ \\
\hline & & & Roadway & Railway & Waterway & $\begin{array}{c}(\mathrm{US} \$ / \mathrm{t}) \\
(\mathrm{A})\end{array}$ & $\begin{array}{c}(\mathrm{US} \$ / \mathrm{t}) \\
\text { (B) }\end{array}$ & $\begin{array}{c}(\mathrm{US} \$ / \mathrm{t}) \\
(\mathrm{C})\end{array}$ & $\begin{array}{c}(\mathrm{US} \$ / \mathrm{t}) \\
(\mathrm{A}+\mathrm{B}+\mathrm{C})\end{array}$ \\
\hline \multirow{5}{*}{ MA } & $\begin{array}{l}\text { Itaqui } \\
\text { (MA) }\end{array}$ & Roadway & 785 & - & - & 117.6 & - & 7.5 & 125.1 \\
\hline & $\begin{array}{l}\text { Itaqui } \\
\text { (MA) }\end{array}$ & $\begin{array}{c}\text { Road and } \\
\text { Railway via } \\
\text { Porto Nacional }\end{array}$ & 892 & 1,282 & - & 102.2 & 3.7 & 7.5 & 113.4 \\
\hline & $\begin{array}{l}\text { Santos } \\
\text { (SP) }\end{array}$ & Roadway & 2,435 & - & - & 295.8 & - & 9.0 & 304.8 \\
\hline & $\begin{array}{c}\text { Santos } \\
\text { (SP) }\end{array}$ & $\begin{array}{c}\text { Road and } \\
\text { Waterway via } \\
\text { São Simão }\end{array}$ & 2,133 & - & 640 & 269.8 & 4.5 & 9.0 & 283.3 \\
\hline & $\begin{array}{l}\text { Aratu } \\
\text { (BA) }\end{array}$ & Roadway & 1,462 & - & - & 190.7 & - & 8.0 & 198.7 \\
\hline \multirow{5}{*}{ TO } & $\begin{array}{l}\text { Itaqui } \\
\text { (MA) }\end{array}$ & Roadway & 1,368 & - & - & 180.5 & - & 7.5 & 188.0 \\
\hline & $\begin{array}{l}\text { Itaqui } \\
\text { (MA) }\end{array}$ & $\begin{array}{c}\text { Road and } \\
\text { Railway via } \\
\text { Porto Nacional }\end{array}$ & 182 & 1,282 & - & 63.2 & 3.7 & 7.5 & 74.4 \\
\hline & $\begin{array}{l}\text { Santos } \\
\text { (SP) }\end{array}$ & Roadway & 1,838 & - & - & 231.4 & - & 9.0 & 240.4 \\
\hline & $\begin{array}{c}\text { Santos } \\
\text { (SP) }\end{array}$ & $\begin{array}{c}\text { Road and } \\
\text { Waterway via } \\
\text { São Simão }\end{array}$ & 1,539 & - & 640 & 205.7 & 4.5 & 9.0 & 219.2 \\
\hline & $\begin{array}{l}\text { Aratu } \\
\text { (BA) }\end{array}$ & Roadway & 1,394 & - & - & 183.4 & - & 8.0 & 191.4 \\
\hline \multirow{5}{*}{ PI } & $\begin{array}{l}\text { Itaqui } \\
\text { (MA) }\end{array}$ & Roadway & 847 & - & - & 124.3 & - & 7.5 & 131.8 \\
\hline & $\begin{array}{l}\text { Itaqui } \\
\text { (MA) }\end{array}$ & $\begin{array}{c}\text { Road and } \\
\text { Railway via } \\
\text { Porto Nacional }\end{array}$ & 894 & 1,282 & - & 98.1 & 3.7 & 7.5 & 109.3 \\
\hline & $\begin{array}{l}\text { Santos } \\
\text { (SP) }\end{array}$ & Roadway & 2,367 & - & - & 288.5 & - & 9.0 & 297.5 \\
\hline & $\begin{array}{c}\text { Santos } \\
\text { (SP) }\end{array}$ & $\begin{array}{c}\text { Road and } \\
\text { Waterway via } \\
\text { São Simão }\end{array}$ & 2,081 & - & 640 & 264.2 & 4.5 & 9.0 & 277.7 \\
\hline & $\begin{array}{l}\text { Aratu } \\
\text { (BA) }\end{array}$ & Roadway & 1,262 & - & - & 169.1 & - & 8.0 & 177.1 \\
\hline \multirow{5}{*}{ BA } & $\begin{array}{l}\text { Itaqui } \\
\text { (MA) }\end{array}$ & Roadway & 1,394 & - & - & 183.4 & - & 7.5 & 190.9 \\
\hline & $\begin{array}{l}\text { Itaqui } \\
\text { (MA) }\end{array}$ & $\begin{array}{c}\text { Road and } \\
\text { Railway via } \\
\text { Porto Nacional }\end{array}$ & 571 & 1,282 & - & 106.9 & 3.7 & 7.5 & 118.1 \\
\hline & $\begin{array}{l}\text { Santos } \\
\text { (SP) }\end{array}$ & Roadway & 1,728 & - & - & 219.5 & - & 9.0 & 228.5 \\
\hline & $\begin{array}{l}\text { Santos } \\
\text { (SP) }\end{array}$ & $\begin{array}{c}\text { Road and } \\
\text { Waterway via } \\
\text { São Simão }\end{array}$ & 1,549 & - & 640 & 206.8 & 4.5 & 9.0 & 220.3 \\
\hline & $\begin{array}{l}\text { Aratu } \\
\text { (BA) }\end{array}$ & Roadway & 916 & - & - & 131.8 & - & 8.0 & 139.8 \\
\hline
\end{tabular}

economy, such as science and technology. However, the logistical sector has not shown the same development, allowing some weaknesses to persist, either due to the lack of infrastructure for production transport, or the inability to properly store produce. For Brazilian agribusiness, logistics intermodality is capable of promoting competitiveness gains, since it minimizes the distribution costs of products destined 
Table 4 - Origin and destination flow for soybean in scenario A (thousand tonnes).

\begin{tabular}{lcccc}
\hline & R1 & R3 & R5 & Total \\
\hline MA & $2,473.3$ & - & - & $2,473.3$ \\
TO & $1,606.6$ & $1,219.8$ & - & $2,826.4$ \\
PI & $2,048.1$ & & - & $2,048.1$ \\
BA & - & $1,955.3$ & $3,168.0$ & $5,123.3$ \\
Total & $6,128.0$ & $3,175.1$ & $3,168.0$ & $12,471.1$ \\
\hline
\end{tabular}

to consumer markets and promotes the rational use of transport modes.

The consolidation of an integrated transport logistics and the use of transport modes based on its economic viability and operational rationality have the capacity to promote the reduction of transport costs and to increase the competitiveness of MATOPIBA soybeans.

An important obstacle for the Brazilian logistics system is the discontinuity of transport infrastructure projects. As OLIVEIRA (2014) pointed out, in 2007 there was a rescue of the logistics projects by the federal government, after two decades of absolute stagnation and lack ofstrategic planning with medium and long term vision, in which it was launched the National Logistics and Transport Plan (PNLT). The objective was to formalize and perpetuate analysis instruments, from the perspective of logistics, to support the planning of public and private interventions in infrastructure and organization of transport.

After that, subsidized by the PNLT, the Growth Acceleration Plan (PAC) began, and in 2011,

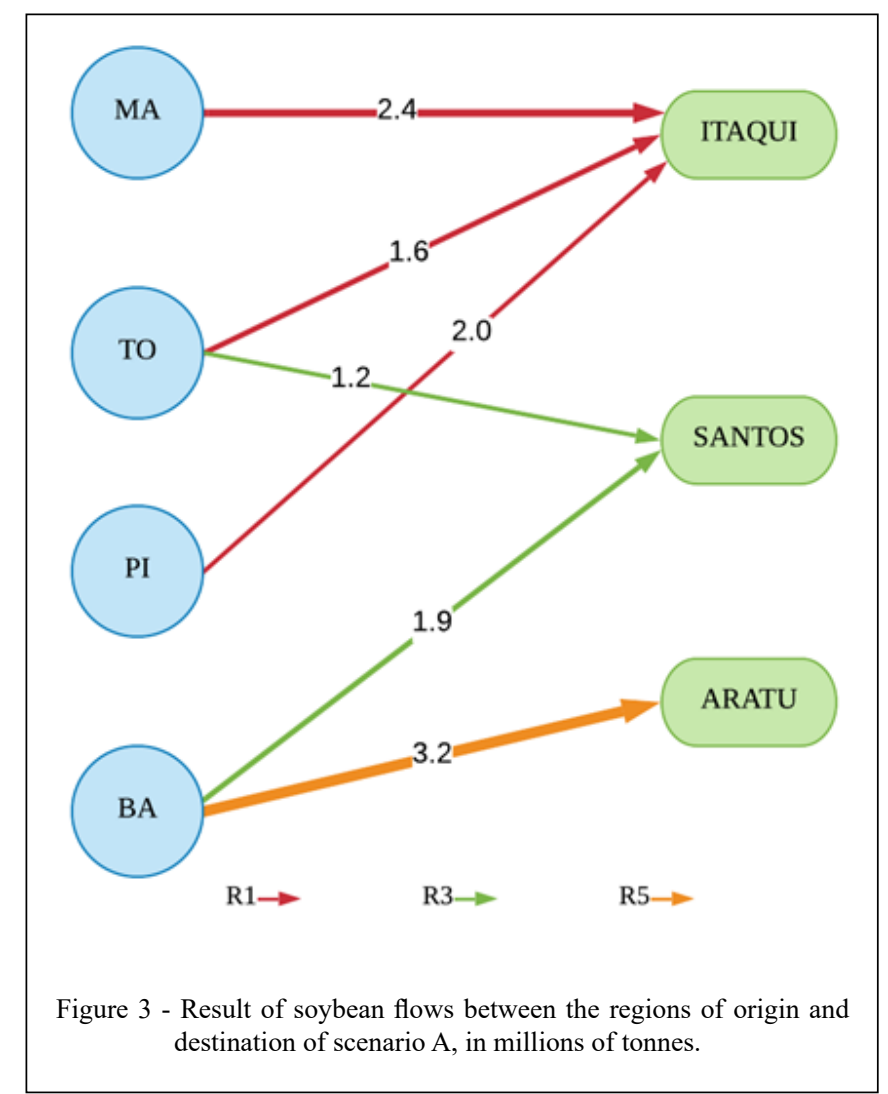

Ciência Rural, v.51, n.2, 2021. 
Table 5 - Origin and destination flow for soybean in scenario B (thousand tonnes).

\begin{tabular}{|c|c|c|c|c|c|c|}
\hline & $\mathrm{R} 1$ & $\mathrm{R} 2$ & $\mathrm{R} 3$ & $\mathrm{R} 4$ & R5 & Total \\
\hline MA & $2,473.3$ & - & - & - & - & $2,473.3$ \\
\hline TO & - & $2,826.4$ & - & - & - & $2,826.4$ \\
\hline PI & 701.8 & $1,346.3$ & - & - & - & $2,048.1$ \\
\hline BA & - & $1,955.3$ & - & - & $3,168.0$ & $5,123.3$ \\
\hline Total & $3,175.1$ & $6,128.0$ & - & - & $3,168.0$ & $12,471.1$ \\
\hline
\end{tabular}

the PAC-2. Both plans set out to stimulate private investment through concessions and infrastructure works, driven by the financial contribution granted by the State (OLIVEIRA, 2014). However, the constant and recent processes of political instability should compromise the development of the transport sector in Brazil.

The expansion of the border into the MATOPIBA region has been taking place since the 1970s, in the wake of the demographic occupation of the Brazilian Midwest. However, the speed in which the new path of agricultural production was established was not matched by transport infrastructure. An example of this is the fact that the North-South Railroad, which connects this region with the North and Northeast ports began its construction in 1987, but only began operating commercially in 2019 .

According to the results herein, the intermodal road-rail route to the Port of Itaqui should undertake the main flow of soybean movement from MATOPIBA to the foreign market, taking advantage of the high capacity of Brazilian railways to transport cargo. This flow was estimated to account for about half of the soybean production volume.

Investments and/or the intention to invest in MATOPIBA are directed to the agro-export

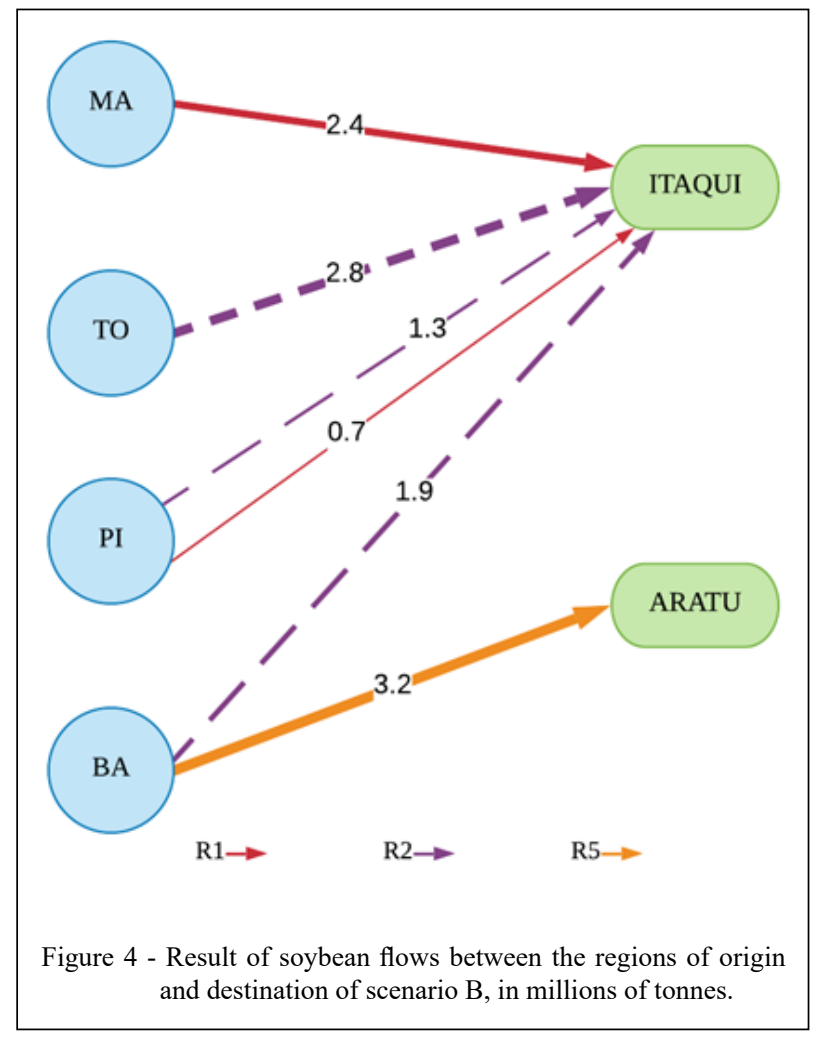

Ciência Rural, v.51, n.2, 2021. 
segment, that is, focused on the flow and exportation of grains. This statement is evident when we evaluate the two largest projects in the region, which are the partially completed North-South Railroad (FNS) and the West East Integration Railroad (FIOL), which is under construction. Both projects were conceived and implemented for the movement of agricultural produce and ore.

Of the scenarios proposed in this paper, scenario B is the most efficient and presents the greatest minimization of the total transportation cost. The distribution of soybeans in this scenario originates from the MATOPIBA region and the destinations are the ports of Itaqui (MA) and Aratu (BA), not using the traditional port of Santos (SP). In addition, the Port of Itaqui (MA) is the optimal destination in both scenarios $\mathrm{A}$ and $\mathrm{B}$. This port is located in northeastern Brazil, allowing greater efficiency in the export of agricultural products from this region, while softening the overload of the main Brazilian ports located in the southeast and south of the country, such as the Port of Santos (SP).

In this context, the optimal outcome of scenario B confirmed the importance and economic viability of using the FNS railroad and the ongoing investments to complete the FIOL railroad. Both projects reinforce the use of the ports of Itaqui and Aratu, relieving the Port of Santos, as well as promoting the decentralization of development and supporting the economic growth of the NorthNortheast Brazilian axis.

\section{ACKNOWLEDGEMENTS}

The research was financed in part by grant \#2018/19571-1, São Paulo Research Foundation (FAPESP) and the Coordenação de Aperfeiçoamento de Pessoal de Nível Superior (CAPES), Brasil - Finance code 001

\section{DECLARATION OF CONFLICT OF} INTERESTS

The authors declared no potential conflicts of interest with respect to the research, authorship, and/o publication of this article.

\section{REFERENCES}

AISHA, T. A.; et al. Optimization of container terminal layouts in the seaport-case of Port of Montreal. Sustainability, v.12, n.3, 2020 Available from: <https://www.mdpi.com/2071-1050/12/3/1165/ htm>. Accessed: Mar. 20, 2020. doi: 10.3390/su12031165.

ADITJANDRA, P. T., et al. Green Rail Transportation: Improving Rail Freight to Support Green Corridors. In: PSARAFTIS H. Green Transportation Logistics. International Series in
Operations Research \& Management Science. Cham: Springer, 2016, pp.413-454. doi: 10.1007/978-3-319-17175-3_12.

BRASIL - Ministério da Agricultura, Pecuária e Abastecimento. Projeções do Agronegócio - Brasil 2016/17 a 2026/27. 2017. Available from: <http://www.agricultura.gov.br/assuntos/politicaagricola/todas-publicacoes-de-politica-agricola/projecoes-doagronegocio/projecoes-do-agronegocio-2017-a-2027-versaopreliminar-25-07-17.pdf.>. Accessed: May, 15, 2018.

BRASIL - Ministério da Economia. ComexStat - Estatísticas do Comércio Exterior. 2020. Available from: <http://comexstat. mdic.gov.br/pt/geral>. Accessed: Feb. 05, 2020.

BUAINAIN, A. M. et al. A economia agropecuária do MATOPIBA Estudos Sociedade e Agricultura, v.26, n.2, p.376-401, 2018. Avaliable from: <https://doi.org/10.36920/esa-v26n2-6>. Accessed: Feb. 6, 2020. doi: 10.36920/esa-v26n2-6.

CASACA, A. C. P. et al. The Brazilian cabotage market: A content analysis. International Journal of Shipping and Transport Logistics, v.9, n.5, p.601-625, 2017. Available from: <https://doi. org/10.1504/IJSTL.2017.086316>. Accessed: Feb. 20, 2020. doi: 10.1504/IJSTL.2017.086316.

CONAB - Companhia Nacional de Abastecimento. Previsão de Safras. 2020. Available from: <https://www.conab.gov.br/infoagro/safras/serie-historica-das-safras $>$. Accessed: Feb. 15, 2020.

CONAB - Companhia Nacional de Abastecimento. Estimativa do escoamento das exportações do complexo soja e milho pelos portos nacionais. Compêndio de Estudos da Conab, v.6, p.1-23, 2016. Available from: $<$ https://www.conab.gov.br/institucional/publicacoes/ compendio-de-estudos-da-conab>. Accessed: Feb. 15, 2018.

CORREA, V. H. C.; RAMOS, P. A precariedade do transporte rodoviário brasileiro para o escoamento da produção de soja do Centro-Oeste: Situação e perspectivas. Revista de Economia e Sociologia Rural, v.48, n.2, p.447-472, 2010. Available from: <https://doi.org/10.1590/S0103-20032010000200009>. Accessed: Feb. 06, 2020. doi: 10.1590/S0103-20032010000200009.

DE LA CRUZ, B. C. B. et al. An application of the spatial equilibrium model to soybean production on Tocantins and neighboring states in Brazil. Pesquisa Operacional, v.3, n.2, p.443-464, 2010. Available from: <https://doi.org/10.1590/S010174382010000200011>. Accessed: Feb. 10, 2020. doi: 10.1590/ S0101-74382010000200011.

FAVARETO, A. et al. Entre chapadas e baixões no MATOPIBA dinâmicas territoriais e impactos socioeconômicos na fronteira da expansão agropecuária no cerrado. São Paulo: Editora Ilustre e Greenpeace, 2019. 272p.

FILASSI, M. Direcionadores de competitividade para exportação da soja brasileira. 2019. 49f. Master's Thesis. (Master in Agricultural Engineering) - Post-graduation Course in Agricultural Engineering, University of Campinas. Available from: $<$ http://repositorio.unicamp.br/jspui/handle/REPOSIP/344435>. Accessed: Feb. 19, 2020.

GORDON, J. R. M. et al. A resource-based view of competitive advantage at the Port of Singapore. Journal of Strategic Information Systems, v.14, p.69-86, 2005. Available from: $<$ https://doi.org/10.1016/j.jsis.2004.10.001>. Accessed: Feb. 20, 2018. doi: 10.1016/j.jsis.2004.10.001. 
HAMERSLAG, R.; IMMERS, B. H. Estimation of trip matrices: shortcomings and possibilities for improvement. Transportation Research Record, n.1203, p.27-39, 1988. Available from: <http:// onlinepubs.trb.org/Onlinepubs/trr/1988/1203/1203-003.pdf>. Accessed: Feb. 7, 2018.

KAWAMOTO, E. Transferability of standardized regression model applied to person-based trip generation. Transportation Planning and Technology, v.26, n.4, p.331-359, 2003. Available from: <http://dx.doi.org/10.1080/03081060310001635896>. Accessed: Mar. 03, 2018. doi: 10.1080/03081060310001635896.

KUSSANO, M. R.; BATALHA, M. O. Custos logísticos agroindustriais: avaliação do escoamento da soja em grão do Mato Grosso para o mercado externo. Gestão \& Produção, v.19, n.3, p.619-632, 2012. Available from: <https://doi.org/10.1590/S0104530X2012000300013>. Accessed: Feb. 13, 2020. doi: 10.1590/ S0104-530X2012000300013.

LEITE, S. C. F.; FIGUEIREDO, M. G. Fluxos de algodão em pluma para exportação no Estado da Bahia: uma aplicação de programação linear. In: CONGRESSO DA SOCIEDADE BRASILEIRA DE ECONOMIA E SOCIOLOGIA RURAL, 44., 2006, Fortaleza, Brazil. Anais..., 2006. Available from: $<$ https:// ageconsearch.umn.edu/record/149116/>. Accessed: Feb. 05, 2020. doi: 10.22004/ag.econ.149116.

LOPES, H. DOS S. et al. A cost optimization model of transportation routes to export the Brazilian soybean. Custos e Agronegócio, v.12, n.4, p.90-109, 2016. Available from: $<$ https://www.researchgate.net/publication/317747161_A_cost optimization_model_of_transportation_routes_to_export_the Brazilian_soybean>. Accessed: Feb. 13, 2020.

MARTINS, R. S.; CAIXETA FILHO, J. V. Análise das contribuições das ferrovias à matriz de transportes para produtos agrícolas no estado do Paraná. Revista de Economia e Sociologia Rural, v.36, n.3, 1998. Available from: <https://esalqlog.esalq. usp.br/martins-r-s-caixeta-filho-j-v-analise-das-contribuicoesdas-ferrovias-a-matriz-de-transporte-para-produtos-agricolas-noestado-do-parana-revista-de-economia-e-sociologia-rural-vol-363-p-33-54-jul-set-1998>. Accessed: May, 10, 2018.

MARTINS, R. S.; CAIXETA FILHO, J. V. Subsídios à tomada de decisão da escolha da modalidade para o planejamento dos transportes no estado do Paraná. Revista de Administração Contemporânea, v.3, n.2, p.75-96, 1999. Available from: <http:// www.scielo.br/pdf/rac/v3n2/v3n2a05.pdf $>$. Accessed: May, 10, 2018. doi: 10.1590/S1415-65551999000200005.

MIRANDA, E. E. et al. Proposta de delimitação territorial do MATOPIBA. Campinas: Embrapa - GITE, 2014. 18p. (Nota Técnica). Available from: <https://ainfo.cnptia.embrapa.br/ digital/bitstream/item/139202/1/NT1-DelimitacaoMatopiba.pdfs . Accessed: Feb. 25, 2020

OLIVEIRA, A. L. R. A logística do agronegócio: para além do apagão logístico. In: BUAINAIN, A. M. et al. O mundo rural no Brasil do século 21: a formação de um novo padrão agrário e agrícola. Brasília: Embrapa, 2014. p.337-370. Available from: <https://www. embrapa.br/busca-de-publicacoes/-/publicacao/994073/o-mundorural-no-brasil-do-seculo-21-a-formacao-de-um-novo-padraoagrario-e-agricola $>$. Accessed: Mar. 25, 2018.

OLIVEIRA, A. L. R.; ALVIM, A. M. The supply chain of Brazilian maize and soybeans: the effects of segregation on logistics and competitiveness. The International Food and Agribusiness Management Review, v.20, n.1, p.45-61, 2017. Available from: $<$ https://doi.org/10.22434/IFAMR2016.0084>. Accessed: Mar. 18, 2018. doi: 10.22434/IFAMR2016.0084.

OLIVEIRA, A. L. R. et al. Aplicação de modelagem matemática para otimização da logística de exportação do milho do Estado do Mato Grosso. Revista em Agronegócios e Meio Ambiente, v.8, n.3, p.505, 2015. Available from: <https://doi.org/10.17765/21769168.2015v8n3p505-522>. Accessed: Mar. 18, 2018. doi: 10.17765/2176-9168.2015v8n3p505-522.

OLIVEIRA, A. L. R. et al. Logística de exportação do açúcar do Estado de São Paulo: uma estimativa da matriz origem-destino. Espacios, v.34, n.12, p.8-18, 2013. Available from: $<$ https://www. revistaespacios.com/a13v34n12/13341209.html>. Accessed: Mar. $18,2018$.

PEREIRA, C. N. et al. Dinâmica Econômica, Infraestrutura e Logística no MATOPIBA. Texto para Discussão (IPEA), v.1, p.1-96, 2018. Available from: <http://repositorio.ipea. gov.br/bitstream/11058/8355/1/td 2382.pdf $>$. Accessed: Feb. 17, 2020.

ROULET, M. C. et al. A Multiple-Criteria Analysis Application for Vertical Coordinate on in the Transportation of Agricultural Commodities in Brazil. Journal of Food Products Marketing, v.22, n.6, p.1-13, 2016. Available from: <https://doi.org/10.10 80/10454446.2015.1121436>. Accessed: Mar. 23, 2018. doi: $10.1080 / 10454446.2015 .1121436$.

SIFRECA - Sistema de Informações de Fretes. Fretes Rodoviários. Available from: <http://sifreca.esalq.usp.br/mercado-de-fretes/ soja/>. Accessed: May, 10, 2018.

SOUZA, C. D. R et al. Modelos de geração de viagens para polos geradores de viagens de cargas. Transportes, vol.18, n.1, pp.4657, 2010. Available from: <https://doi.org/10.14295/transportes. v18i1.396>. Accessed: Feb. 15, 2018. doi: 10.14295/transportes. v18i1.396.

SOUZA, R. O. et al. Análise dos valores de frete da soja a granel nos sistemas unimodal e multimodal de transporte. Revista em Agronegócio e Meio Ambiente, v.9, n.4, p.819837, 2016. Available from: <https://doi.org/10.17765/21769168.2016v9n4p819-837>. Accessed: Feb. 20, 2020. doi: 10.17765/2176-9168.2016v9n4p819-837.

TOLOI, R. C. et al. Fatores de decisão e qualidade na rede de suprimentos da soja de Mato Grosso. Revista Agrarian, v.12, n.44, p.248-260, 2019. Available from: <http://ojs.ufgd.edu.br/ index.php/agrarian/article/view/9210>. Accessed: Feb. 13, 2020. doi: 10.30612/agrarian.v12i44.9210.

TUNDE, A. M.; ADENIYI, E. E. Impact of road transport on agricultural development: a Nigerian example. Ethiopian Journal of Environmental Studies and Management, v.5, n.3, p.232-238, 2012. Available from: <http://dx.doi.org/10.4314/ejesm.v5i3.3>. Accessed: Feb. 17, 2020. doi: 10.4314/ejesm.v5i3.3.

VALEC - Engenharia, Construções e Ferrovias SA. Ferrovias. Available from: <http://www.valec.gov.br/ferrovias/ferrovianorte-sul>. Accessed: May, 28, 2018.

WIEGMANS, B.; JANIC, M. Analysis, modeling, and assessing performances of supply chains served by long- 
distance freight transport corridors. International Journal of Sustainable Transportation, v.13, n.4, p.278-293, 2019. Available from: <https://www.tandfonline.com/doi/full/10.10 80/15568318.2018.1463419>. Accessed: Mar. 25, 2020. doi: $10.1080 / 15568318.2018 .1463419$.

WU, Y. C. J.; LIN, C. W. National port competitiveness: implications for India. Management Decision, v.3, n.46, p.1482-1507, 2008. Available from: <https://www.researchgate.
net/publication/235291941_National_port_competitiveness Implications for India $>$. Accessed: Feb. 15, 2018. doi: 10.1108/00251740810920001.

YANG, X. et al. Computational optimization, modelling and simulation: recent trends and challenges. Procedia Computer Science, v.18, p.855-860, 2013. Available from: $<$ https://core. ac.uk/download/pdf/82234562.pdf>. Accessed: Feb. 17, 2020. doi: 10.1016/j.procs.2012.04.091. 